\author{
ACTA MYCOLOGICA \\ Vol. 44 (1): 97-107 \\ 2009
}

\title{
Yeast-like fungi isolated from indoor air in school buildings and the surrounding outdoor air
}

\author{
ELŻBIETA EJDYS, JOANNA MICHALAK and KATARZYNA MONIKA SZEWCZYK
}

\author{
Department of Mycology, University of Warmia and Mazury in Olsztyn \\ Oczapowskiego 1A, PL-10-719 Olsztyn-Kortowo, elzbieta.ejdys@uwm.edu.pl
}

Ejdys E., Michalak J., Szewczyk K. M.: Yeast-like fungi isolated from indoor air in school buildings and the surrounding outdoor air. Acta Mycol. 44 (1): 97-107, 2009.

A total of 111 isolates of yeast-like fungi and yeasts belonging to 40 species of 19 genera were identified in indoor air and outdoor air. Only one species, Kluyveromyces marxianus, was recorded in both types of air and seasons (spring and autumn). Kluyveromyces lactis and Yarrowia lipolytica, a species having the greatest symbiotic abilities, dominated in indoor air and outdoor air, respectively. Intensely used rooms, especially those with limited access of air, have the broadest range of species of yeast-like fungi. A comparison of both habitats shows that school rooms pose a greater epidemiological risk of yeast-like infections than outdoor air. The indoor as well as outdoor mycobiota undergoes phenological changes although it is determined by other biotic and abiotic factors.

Key words: yeast-like fungi, school, indoor air

\section{INTRODUCTION}

Fungal spores and mycelium fragments constitute the greatest part of bioaerosols in indoor air (Krzysztofik 1992). They use air as a vector between living organisms and water, soil and abiotic ecosystem components (Dynowska, Ejdys 1999). Similarly to outdoor air, indoor air aerosol contains biological particles. Fungal spores in indoor air are consistent with the seasonal development of individual species in nature (Twarużek 2006).

The accumulation of cellulose and lignin sources: construction wood, furniture (Zyska 2001), plywood, paper, fireboard and chipboard (Miklaszewska, Grajewski 2006), as well as other sources: plaster, paint (Zyska 2001; Grajewski, Twarużek 2004), provides favourable conditions for the development of indoor fungi. Although the taxonomical range of the mycobiota of different types of air is very broad, moulds dominate in it (Zyska 2001; Ejdys 2007; Topbas et al. 2006). However, the 
prevalence of yeast-like fungi does not exceed $10 \%$ in indoor air in buildings having normal humidity and temperature parameters (Ejdys 2007) and can reach a maximum of $20 \%$ in particularly damp rooms (Meklin et al. 2002). This is surprising given special enzymatic abilities and a high rate of proliferation and growth of yeastlike fungi. They have been isolated from biotic and abiotic ecosystem components in all climatic zones (Dynowska 1995; Kurnatowska 1998; Bogacka, Matkowski 2001; Arias et al. 2002; Nagornaya et al. 2003; Biegańska 2006). A large group of potentially pathogenic species mostly of the genera Candida, Kluyveromyces, Debaryomyces, Rhodotorula, Pichia, Trichosporon, Sacharomycopsis (Dynowska 1995) and recently also Saccharomyces (Dynowska et al. 2006) or Zygoascus (Brandt et al. 2004) has been identified within yeast-like fungi. They are usually an aetiological factor in mycoses and, less frequently, in mycoallergies. As they can produce toxins (e.g. candotoxins), the species can cause mycotoxycoses and increase micro-organism sensitivity to some bacterial infections (Dynowska 1995).

Age is the main physiological factor of the school period that predisposes to fungal infections. The risk of mycoses increases as other epidemiological factors occur, e.g. a child spends time in a large same-age group in the same rooms for several hours. Children spend between 5 and 9 hours on the school premises daily and it is of mycological importance how clean school buildings and their surroundings are.

Heavier than mould spores, spores of yeast-like fungi are located in the lower part of the air column (Stach et al. 2004). They can rise up to a height of $>1.5 \mathrm{~m}$ as a result of air currents related to human movement (Kurnatowska 1999). The two most important infection portals, the nose and the mouth, are located at this height in primary school children. Therefore, a high accumulation of yeast-like fungi in the air can pose a serious threat to the health of children inhaling this air (Kurnatowska 1999; Meklin et al. 2002).

\section{MATERIAL AND METHODS}

Schools in Olsztyn (165 000 inhabitants) and Dobre Miasto (11 000 inhabitants) were selected. Both Olszytn and Dobre Miasto are situated in the Pojerzezie Olsztyńskie lakeland. Lower temperatures and a shorter vegetation period in comparison with other parts of Poland are observed in the area (Kondracki 2002).

Yeast-like fungi occurring temporarily in outdoor and indoor air were examined. Fungi were collected in May (central heating switched off) and in November (heating operating).

Koch sedimentation method was used to obtain the material. Petri dishes with both types of Sabouraud's medium (chloramphenicol and Rose-Bengal) were exposed at each site in three replicates. Thirteen sites were established around the school building and the gymnasium in Olsztyn (school A) and twelve in Dobre Miasto (school B). Dishes were placed at building corners, at half the wall length, 1.5 $\mathrm{m}$ away from the wall. Samples were also taken from the internal patio in school A. The exposure time was $10 \mathrm{~min}$. A total of 13 different areas inside the school were selected on the ground floor (classroom, women's toilet, men's toilet, corridor and 
sports changing room) and in the basement (cloakroom) as well as in the newly refurbished common room for PE teachers (school A only). Samples containing both media were placed directly on the floor diagonally in two corners of each room. The exposure time was $30 \mathrm{~min}$. Humidity and temperature were measured at each site.

Samples were incubated at $37^{\circ} \mathrm{C}$ for the first three days and transferred to room temperature for 72 hours. Isolates of yeast-like fungi and yeasts were inoculated on Sabouraud's medium without antibiotics. Media containing antibiotics that could affect typical fungal properties were not used (Dynowska 1991-1992).

After pure bacteria-free strains were obtained, microcultures were established on Nickerson agar. Fungi were inoculated on glass slides covered with a thin layer of the medium (ca. $2 \mathrm{~mm}$ ). Two-three drops of broth with serum (1:1) were placed on the inoculation site. Microcultures were incubated at $37^{\circ} \mathrm{C}$ for a period from 48 to 72 hours.

Macroscopic features (size, colour, shape, texture, smell of the colony), microscopic features (shape and size of budding cells, blastospores and chlamydospores, the diameter of pseudohyphae and hyphae) and biochemical features obtained on bio-Mérieux API-tests (API 20C, API 20C AUX) were used for identification. CHROMagar (bio-Mérieux) was used to differentiate individual species of the genus Candida. CHROMagar was treated as an auxiliary test as it does not yield accurate results in mixed-species isolations (Bouchara et al. 1996). Photographic documentation was made throughout the process.

Yeast-like fungi and yeasts were determined using the following keys: Kreger van Rij (1984), Barnett, Payne and Yarrow (1990), and Kurtzmann and Fell (2000).

\section{RESULTS}

A total of 111 isolates of yeast-like fungi and yeasts belonging to 40 species $(+1$ undetermined) of 19 genera were obtained (Tab. 1). The greatest numbers of representatives were recorded for the genera Kluyveromyces and Pichia (6 species), followed by Candida (5), Debaryomyces (4) and Rhodosporidium (2). Other genera occurred incidentally. Kluyveromyces was one of the most frequently recorded genera (24 isolates) as regards the quantity; fungi of the genera Debaryomyces and Pichia were recorded slightly less frequently (18 and 15 isolates, respectively).

Kluyveromyces lactis dominated in both schools. It was, however, isolated only from indoor air when central heating was on. D. polymorphus was also recorded only in autumn, but it was present indoors and outdoors. Only one species, Kluyveromyces marxianus, was recorded in both types of the air and in both seasons.

Three groups of survival in air were distinguished: I - species isolated only from indoor air, II - species isolated only from outdoor air, and III (Tab. 1) - species that survived in both types of air aerosol. Group I was the most numerous one (20 of the 40 taxa identified in the study). Group III was only $20 \%$ and comprised the following fungi: Aureobasidium pullulans, Debaryomyces occidentalis, D. polymorphus, Kluyveromyces marxianus, Oosporidium margaritiferum, Pichia membranifaciens, Saccharomycopsis capsularis, Yarrowia lipolytica. Although it was recorded six times 
Table 1

Yeast-like fungi in May and November in indoor air and outdoor air

\begin{tabular}{|c|c|c|c|c|c|c|c|c|c|}
\hline \multirow[t]{4}{*}{ No } & \multirow[t]{4}{*}{ Species } & \multicolumn{8}{|c|}{ Number of isolates } \\
\hline & & \multicolumn{4}{|c|}{ Indor air } & \multicolumn{4}{|c|}{ Outdoor air } \\
\hline & & \multicolumn{2}{|c|}{ School A } & \multicolumn{2}{|c|}{ School B } & \multicolumn{2}{|c|}{ Around A } & \multicolumn{2}{|c|}{ Around B } \\
\hline & & May* & Nov. & May & Nov. & May & Nov. & May & Nov. \\
\hline 1 & $\begin{array}{l}\text { Arxula adeninivarans van der Walt, Smith } \\
\text { \& Yamada }\end{array}$ & & $1^{\mathrm{III}{ }^{* *}}$ & & & & & & \\
\hline 2 & A. terrestris van der Wald, Smith \& Yamada & & & & & & 1 & & \\
\hline 3 & Aureobasidium pullulans Arn & & & $2^{\mathrm{II}, \mathrm{V}}$ & & 2 & & 3 & \\
\hline 4 & Candida albicans Berkhout & & & & & & & & 1 \\
\hline 5 & C. glabrata Meyer \& Yarrow & $1^{\mathrm{V}}$ & $1^{\mathrm{II}}$ & & & & & & \\
\hline 6 & $\begin{array}{l}\text { C. rhagii Jurzitza, Kühlwein \& Kreger-van } \\
\text { Rij }\end{array}$ & & & & $1^{\mathrm{II}}$ & & & & \\
\hline 7 & C. solani Lodder \& Kreger-van Rij & & & $1^{\mathrm{III}}$ & & & & & \\
\hline 8 & Candida utilis Lodder \& Kreger-van Rij & & & $1^{\mathrm{II}}$ & & & & & \\
\hline 9 & $\begin{array}{l}\text { Cystofilobasidium informominiatum } \\
\text { Hamamoto, Sugiyama \& Komagata }\end{array}$ & $3^{\mathrm{IV}, \mathrm{V}}$ & $1^{\mathrm{VII}}$ & & & & & & \\
\hline 10 & $\begin{array}{l}\text { Debaryomyces hansenii Lodder \& Kreger- } \\
\text { van Rij }\end{array}$ & & $1^{\mathrm{V}}$ & $1^{\mathrm{I}}$ & $3^{\mathrm{II}, \mathrm{V}}$ & & & & \\
\hline 11 & D. occidentalis Kurtzman \& Robnett & & & & $1^{\mathrm{IV}}$ & & & 1 & \\
\hline 12 & D.polymorphus Price \& Phaff & & $1^{\mathrm{II}}$ & & $4^{\mathrm{I}, \mathrm{III}, \mathrm{VI}}$ & & 2 & & 3 \\
\hline 13 & D. venrijiae Abadie, Pignal \& Jacob & & $1^{\mathrm{II}}$ & & & & & & \\
\hline 14 & $\begin{array}{l}\text { Geotrichum clavatum de Hoog, Smith \& } \\
\text { Gueho }\end{array}$ & & & & & & & 2 & \\
\hline 15 & $\begin{array}{l}\text { Kluyveromyces blattae Henninger \& } \\
\text { Windisch }\end{array}$ & & & & & & 1 & & \\
\hline 16 & K. lactis van der Walt & & $6^{\mathrm{III}, \mathrm{IV}, \mathrm{V}, \mathrm{VI}}$ & & $6^{\mathrm{II}, \mathrm{III}, \mathrm{IV}, \mathrm{V}}$ & & & & \\
\hline 17 & K. marxianus van der Walt & & & & $3^{\mathrm{I}, \mathrm{III}}$ & 1 & 1 & 1 & 2 \\
\hline 18 & K. thermotolerans Yarrow & & $1^{\mathrm{I}}$ & & $1^{\mathrm{III}}$ & & & & \\
\hline 19 & K. wickerhamii van der Walt & & & $1^{\mathrm{V}}$ & $1^{\mathrm{V}}$ & & & & \\
\hline 20 & $\begin{array}{l}\text { K. yarrowii van der Walt, Johannsen, } \\
\text { Opperman \& Halland }\end{array}$ & & & & $1^{\mathrm{II}}$ & & & & \\
\hline 21 & Kluyveromyces sp. & & & & & & & & 1 \\
\hline 22 & $\begin{array}{l}\text { Leucosporidium scottii Fell, Statzell, } \\
\text { Hunter \& Phaff }\end{array}$ & & & & & 1 & & & \\
\hline 23 & $\begin{array}{l}\text { Lipomyces starkeyi Lodder \& Kreger-van } \\
\text { Rij }\end{array}$ & & & $1^{\mathrm{V}}$ & & & & & \\
\hline 24 & Mrakia frigida Yamada \& Komagata & $1^{\mathrm{IV}}$ & & $1^{\mathrm{II}}$ & & & & & \\
\hline 25 & Nadsonia commutata Golubev & $2^{\mathrm{V}}$ & & & & & & & \\
\hline 26 & Oosporidium margaritiferum Stautz & & & & $1^{\mathrm{Vi}}$ & & & 1 & \\
\hline 27 & Pichia anomala Kurtzman & & & & $1^{\mathrm{II}}$ & & & & \\
\hline 28 & $\begin{array}{l}\text { P.burtonii Boidin, Pignal, Lehodey, Vey \& } \\
\text { Abadie }\end{array}$ & & & & & & 1 & & \\
\hline 29 & P.delftensis Bebech & & & & & 1 & & & \\
\hline 30 & P.farinosa Hansen & $2^{\mathrm{IV}, \mathrm{V}}$ & & $2^{\mathrm{IV}, \mathrm{VI}}$ & $3^{\mathrm{II}, \mathrm{V}, \mathrm{VI}}$ & & & & \\
\hline 31 & P.guilliermondii Wickerham & & & & & & 2 & & \\
\hline 32 & P.membranifaciens Hansen & & & $1^{\mathrm{VI}}$ & $1^{\mathrm{I}}$ & & 1 & & \\
\hline 33 & $\begin{array}{l}\text { Rhodosporidium dacryoideum Fell, Hunter } \\
\text { \& Tallman }\end{array}$ & $1^{\mathrm{III}}$ & & & & & & & \\
\hline 34 & R. toruloides Banno & $1^{\mathrm{IV}}$ & & & & & & & \\
\hline 35 & Rhodotorula glutinis Harrison & & & $1^{\mathrm{V}}$ & & & & & \\
\hline 36 & Saccharomyces bayanus Saccardo & & & & & & 1 & & \\
\hline 37 & Saccharomycopsis capsularis Schiönning & & & & $1^{\mathrm{VI}}$ & & & & 1 \\
\hline 38 & S.vini van der Walt \& Scott & & & & & & & & 2 \\
\hline 39 & Yarrowia lipolytica van der Walt \& von Arx & & & & $2^{I I, V I}$ & & & & 6 \\
\hline 40 & Zygoascus hellenicus Smith & & & & & 1 & 2 & & \\
\hline 41 & Zygosaccharomyces rouxii Yarrow & & & & & & 3 & & \\
\hline & & 11 & 13 & 12 & 30 & 6 & 15 & 8 & 16 \\
\hline & Total & & 6 & & & & 4 & & \\
\hline
\end{tabular}

Abbreviations: *- isolation month; ** - number of isolates indoors: I-classroom, II-women's toilet, III-men's toilet, IV-corridor, V-cloakroom, VI-sports changing room, VII-common room (PE teachers). 
Table 2

Co-occurrence of species of yeast-like fungi

\begin{tabular}{|c|c|c|c|c|c|c|}
\hline \multirow[t]{2}{*}{ No } & \multirow[t]{2}{*}{ Name of the species } & \multicolumn{5}{|c|}{ Occurrence } \\
\hline & & single & two & species & $\begin{array}{c}\text { three } \\
\text { species }\end{array}$ & four species \\
\hline 1 & Arxula adeninivorans & $\mathrm{X}$ & & & & \\
\hline 2 & Arxula terrestris & & 9 & & & \\
\hline 3 & Aureobasidium pullulans & $\mathrm{X}$ & & $\overline{9}$ & & \\
\hline 4 & Candida albicans & & & & & p \\
\hline 5 & Candida glabrata & & 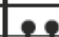 & & & \\
\hline 6 & Candida rhagii & & & $P$ & & \\
\hline 7 & Candida solani & $\mathrm{X}$ & & & & \\
\hline 8 & Candida utilis & & & 6 & & \\
\hline 9 & Cystofilobasidium informominiatum & $\mathrm{X}$ & 8 & & & \\
\hline 10 & Debarvomvces hansenii & $\bar{X}$ & & & & \\
\hline 11 & Debaryomyces occidentalis & $\bar{X}$ & & & & \\
\hline 12 & Debaryomyces polymorphus & $\mathrm{X}$ & 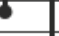 & 9 & $\varphi$ & 5 \\
\hline 13 & Debaryomyces venrijiae & & 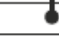 & & & \\
\hline 14 & Geotrichum clavatum & $\mathrm{X}$ & & & & \\
\hline 15 & Kluvvermvces lactis & $\mathrm{X}$ & & & & \\
\hline 16 & Kluvvermyces marxianus & $\mathrm{X}$ & & & 5 & \\
\hline 17 & Kluyvermyces thermotolerans & $\bar{X}$ & & & & \\
\hline 18 & Kluyvermyces wickerhamii & $\mathrm{X}$ & & & & \\
\hline 19 & Kluvvermyces varrowii & $\mathrm{X}$ & & & & \\
\hline 20 & Kluvveromvces blattae & $\bar{X}$ & & & & \\
\hline 21 & Kluvweromvces sp. & & 2 & & & \\
\hline 22 & Leucosporidium scotti & $\mathrm{X}$ & & & & \\
\hline 23 & Lipomyces starkeyi & & & 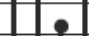 & & \\
\hline 24 & Mrakia frigida & $\mathrm{X}$ & & & & \\
\hline 25 & Nadsonia commutata & $\mathrm{X}$ & & & & \\
\hline 26 & Oosporidium margaritiferum & $\mathrm{X}$ & & & & \\
\hline 27 & Pichia anomala & $\bar{X}$ & & & & \\
\hline 28 & Pichia burtonii & $\bar{X}$ & & & & \\
\hline 29 & Pichia delfensis & $\mathrm{X}$ & & & & \\
\hline 30 & Pichia farinosa & $\mathrm{X}$ & & $d$ & & \\
\hline 31 & Pichia guilliermondii & $\mathrm{X}$ & & & & \\
\hline 32 & Pichia membranifaciens & $\bar{X}$ & & & & \\
\hline 33 & Rhodosporidium dacryoideum & $\mathrm{X}$ & & & & \\
\hline 34 & Rhodosporidium toruloides & $\bar{X}$ & & & & \\
\hline 35 & Rhodotorula glutinis & & & 6 & & \\
\hline 36 & Saccharomyces bayanus & $\mathrm{X}$ & & & & \\
\hline 37 & Saccharomvcopsis capsularis & & & & & \\
\hline 38 & Saccharomycopsis vini & & 19 & & & \\
\hline 39 & Yarrowia lipolytica & & 65 & 56 & 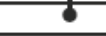 & 5 \\
\hline 40 & Zygoascus hellenicus & $\bar{X}$ & & & & \\
\hline 41 & Zygosaccharomyces rouxii & $\mathrm{x}$ & & & & \\
\hline
\end{tabular}

indoors, Y. lipolytica never occurred on its own (Tab. 2). It co-occurred with one species, Saccharomycopsis vini or Kluyveromyces sp., two species, D. polymorphus and $K$. manxianus, and even three species, $C$. albicans, $D$. polymorphus and $S$. capsularis. It was also always isolated in indoor air with other species: Candida rhagii or $D$. polymorphus. Nine of the 40 determined taxa co-occurred with at least one species $(22.5 \%)$.

More fungi were isolated in both indoor and outdoor air in autumn than in spring (68.9\% and $65.2 \%$, respectively). No relationship was observed between high prevalence of fungi and species differentiation in indoor air. The difference between the occurrence frequency of fungi in spring and autumn did not exceed $1.5 \%$. 
Table 3

Species diversity and the directions of the world

\begin{tabular}{|c|c|c|c|c|c|}
\hline \multicolumn{2}{|c|}{ North-west } & \multicolumn{2}{|c|}{ North } & \multicolumn{2}{|c|}{ North-east } \\
\hline species & $\begin{array}{l}\text { school, } \\
\text { isolation } \\
\text { month }\end{array}$ & species & $\begin{array}{l}\text { school, } \\
\text { isolation } \\
\text { month }\end{array}$ & species & $\begin{array}{l}\text { school, } \\
\text { isolation } \\
\text { month }\end{array}$ \\
\hline $\begin{array}{l}\text { D. polymorphus } \\
\text { Z. hellenicus } \\
\text { A. pullulans }\end{array}$ & $\begin{array}{l}\text { S-1,Nov.* } \\
\text { S-1,May } \\
\text { S-1,May }\end{array}$ & & & $\begin{array}{l}\text { A. terrestris } \\
\text { D. polymorphus } \\
\text { K. blattae } \\
\text { S. bayanus } \\
\text { Z. hellenicus } \\
\text { C. albicans } \\
\text { D. polymorphus } \\
\text { S. capsularis } \\
\text { S. vini } \\
\text { Y. lipolytica }\end{array}$ & $\begin{array}{l}\text { S-1,Nov. } \\
\text { S-1,Nov. } \\
\text { S-1,Nov. } \\
\text { S-1,Nov. } \\
\text { S-1,Nov. } \\
\text { S-2,Nov. } \\
\text { S-2,Nov. } \\
\text { S-2,Nov. } \\
\text { S-2,Nov. }\end{array}$ \\
\hline \multicolumn{2}{|l|}{ West } & \multicolumn{2}{|c|}{ Patio } & \multicolumn{2}{|l|}{ East } \\
\hline $\begin{array}{l}\text { K. marxianus } \\
\text { P. guilliermondii } \\
\text { P. membranifaciens } \\
\text { A. pullulans } \\
\text { D. occidentalis } \\
\text { K. marxianus } \\
\text { O. margaritiferum }\end{array}$ & $\begin{array}{l}\text { S-1,Nov. } \\
\text { S-1,Nov. } \\
\text { S-1,Nov. } \\
\text { S-2,May } \\
\text { S-2,May } \\
\text { S-2,May } \\
\text { S-2,May }\end{array}$ & $\begin{array}{l}\text { A. pullulans } \\
\text { G. clavatum }\end{array}$ & $\begin{array}{l}\text { S-2,May } \\
\text { S-2,May }\end{array}$ & $\begin{array}{l}\text { P. burtonii } \\
\text { P. guilliermondii } \\
\text { Z. rouxii } \\
\text { A. pullulans } \\
\text { L. scottii } \\
\text { P. delftensis } \\
\text { D. polymorphus } \\
\text { K. marxianus } \\
\text { Y. lipolytica }\end{array}$ & $\begin{array}{l}\text { S-1,Nov. } \\
\text { S-1,Nov. } \\
\text { S-1,Nov. } \\
\text { S-1,May } \\
\text { S-1,May } \\
\text { S-1,May } \\
\text { S-2,Nov. } \\
\text { S-2,Nov. } \\
\text { S-2,Nov. }\end{array}$ \\
\hline \multicolumn{2}{|c|}{ South-west } & \multicolumn{2}{|c|}{ South } & \multicolumn{2}{|c|}{ South-east } \\
\hline $\begin{array}{l}\text { G. clavatum } \\
\text { Kluyveromyces sp. } \\
\text { Y. lipolytica }\end{array}$ & $\begin{array}{l}\text { S-2,May } \\
\text { S-2,Nov. } \\
\text { S-2,Nov. }\end{array}$ & $\begin{array}{l}Z . \text { rouxii } \\
K . \text { marxianus }\end{array}$ & $\begin{array}{l}\text { S-1,Nov. } \\
\text { S-1,May }\end{array}$ & $\begin{array}{l}\text { A. pullulans } \\
\text { S. vini } \\
\text { Y. lipolytica }\end{array}$ & $\begin{array}{l}\text { S-1,May } \\
\text { S-2,Nov. }\end{array}$ \\
\hline
\end{tabular}

Abbreviations: *S-1 school 1, S-2 school 2.

The broadest taxonomical range of fungi in indoor air was recorded in the cloakroom (14 species) and in the women's toilet (13 species). Fungi isolated in the cloakroom did not occur in outdoor air (Tab. 1). Fewer species were recorded in the air in the corridor, men's toilet and sports changing room. The abundance of fungi in the classroom was almost three times smaller (five species): D. hansenii, D. polymorphus, $K$. marxianus, K. thermotolerans and $P$. membranifaciens. Only one species, Cystophilobasidium informominiatum, was identified in the PE teachers' common room. Kluyveromyces lactis was recorded in the air of five different rooms. Pichia farinosa was isolated slightly less frequently (4 rooms).

A certain relationship between the occurrence of yeast-like fungi and the site's microgeographic location was observed (Tab. 3). The greatest specific range was observed at eastern sites. A total of 22 isolated were recorded in the east, north-east and southeast. No fungi examined in the study were recorded in the samples at northern sites.

The amplitude of indoor air was the same in spring and in autumn when central heating was on $\left(2.2^{\circ} \mathrm{C}\right)$ and ranged from $19.4^{\circ} \mathrm{C}$ to $21.6^{\circ} \mathrm{C}$ and from $18.4^{\circ} \mathrm{C}$ do $20.6^{\circ} \mathrm{C}$, respectively. Relative air humidity ranged from $48 \%$ and $60 \%$ regardless of the season.

Temperature and humidity of outdoor air ranged considerably depending on site location. Temperature ranged from 21.2 to $33.6^{\circ} \mathrm{C}$ in Olsztyn and from 18.2 to $22.7^{\circ} \mathrm{C}$ in Dobre Miasto in spring, and was (14.2:22.7) and (8.3:14.2) in autumn. Air humidity was 33-67\% (Olsztyn) and 42-50\% (Dobre Miasto) in May. It was higher in November and was 46-65\% in Olsztyn and 62-92\% in Dobre Miasto. 


\section{DISCUSSION}

Current studies usually focus on threats posed by yeast-like fungi to human and animal health. Studies in applied mycology related to human economy are numerous (Hahn et al. 2006; Golubev et al. 2003; Angerbauer et al. 2008). However, up-to-date reports on basic research into natural habitats of yeast-like fungi that concentrates on humans are scarce. It is therefore difficult to determine whether 40 species of yeast-like fungi isolated in the study in urban conditions in Central Europe are an exceptional figure or if they are typical of this environment. The lack of reports on the occurrence of yeast-like fungi in air samples may be connected with methodological problems. Cultures should not be interfered with in the initial phase of incubation to avoid sample contamination and to identify the full mycobiota range. It is often possible to isolate yeast-like fungi only at the beginning of culture as fast-growing moulds destroy them. The use of substrates suitable for the development of moulds (Czapek-Dox) recommended in the Polish Standard (PN 89/Z04111/03) additionally promotes them. Incubation temperature $\left(26^{\circ} \mathrm{C}\right)$ also promotes the majority of moulds and not only slightly more thermophilous fungi that also include some yeast-like fungi. For instance, Arxula adeninivorans, which can grow up to a temperature of $48^{\circ} \mathrm{C}$ (Wartman, Kunze 2000; Kunze 2006), was obtained in the study by using an incubation temperature higher $\left(37^{\circ} \mathrm{C}\right)$ than that recommended for the examination of air mycobiota.

A broad temperature range seems to be a key factor in the ecological success of Kluyveromyces marxianus, which was recorded in both types of air in spring and autumn. It can survive in different temperature ranges and can therefore function in water, on plants or in human or animal bodies (Dynowska 1995; Kurtzmann, Fell 2000). Broad enzymatic abilities allow it to ferment available sugars and different sources of carbon of both plant and animal origin. Its ability to colonise different ecological niches may also be attributed to the type of its reproduction. Kluyveromyces marxianus combines rapid reproduction by budding in favourable conditions with alterations of genetic information during unfavourable environmental changes by producing ascospores.

Another ascomycete, Kluyveromyces lactis, occurs mostly in milk and milk-derived products (Kurzman, Fell 2000). Its relatively rare ability to ferment and assimilate lactose allows the species to dominate in environments where it is available. Small cartons of short-lifetime milk were distributed at school and the species was prevalent in the study. Food remains may also have been a source of and/or substrate for Debaryomyces occidentalis, D. hansenii or Mrakia frigida. Although they are used in biotechnology and the food industry (Mazurkiewicz-Zapałowicz 2006), they can also contaminate ready products (Moreira et al. 2001).

Aureobasidium pullulans and Pichia farinose, species dominating in school B in spring, may have come from outdoors. Soil, cereal crops and their products are natural environments of occurrence of these fungi (Twarużek 2006; Kurzman, Fell 2000). Pupils or the staff may also have been a source of them as these fungi have been isolated from people (Salkin et al. 1986; Bolignano, Criseo 2003; Garcia-Martos et al. 1996). The presence of $A$. pullulans in indoor air can intensify asthma symptoms (Niedorzytko et al. 2007) or lead to the development of pulmonary hypersensitivity to its spores (Temprano et al. 2007). 
Conditions favourable for the occurrence and existence of different fungi are identified in intensely used rooms with a high through-put of people (cloakroom, walkways or passages). A broad range of fungi belonging to different systematic and ecological groups vegetates on organic matter from occupants' bodies (dead epidermis, saliva, hair) or clothes, shoes or functional items. As the occurrence of moulds having especially high toxinogenic abilities in such rooms shows, increased competition is also associated with mycobiota richness (Ejdys 2008). Organic compounds formed from lysis of dead fungal and bacterial cells accumulate in indoor aerosol with an abundant mycobiota. They can provide a particularly suitable substrate for the development of yeast-like fungi.

Fungi can increase survival potential in difficult environmental conditions by expanding their enzymatic range and entering symbiosis with other organisms, even other fungi. Yarrowia lipolytica occurred exclusively with other fungi in the study. Co-occurring species have a broader range of fermentation and assimilation abilities than Y. lipolytica, which does not ferment and its carbon sources are limited only to glucose and partly galactose.

The occurrence of organisms in the same habitat may show similar or overlapping parameters of their ecological niches. Fungi such as Cystofilobasidium infirmominiatum, Rhodotorula glutinis and Debaryomyces hansenii were isolated from air in the cloakroom in the study. This seems to be connected with the fact that these fungi prefer similar organic compounds as the same set of fungi has been isolated from poultry meat (Deak 2001) and from human clinical material (Kurzman, Fell 2000; Desnos-Ollivieri et al. 2008; Ejdys 2008). Although the species have been isolated from plant material (Kurzman, Fell 2000; Golubev et al. 2003), their presence in school buildings is connected with the human body and its excretions or secretions rather than with plant tissues and can pose a potential threat to the health of building occupants.

Relatively constant temperature and humidity conditions in relation to outdoor sites are observed indoors. Moreover, light access is limited even on sunny days in the cloakrooms which are located in the basement. This may explain the indoor occurrence of yeast-like fungi that were not recorded in outdoor air. They may belong to "domestic fungi", such as Aspergillus or Penicillium, especially as permanent exposure of the cloakroom to outdoor air did not considerably influence the composition of the mycobiota of yeast-like fungi as shown by the absence of species that occurred in outdoor air at the same time.

Yeast-like fungi that occurred only in outdoor air samples may be treated as "field fungi". These fungi or only some of their strains are less sensitive to high daily temperature and humidity amplitudes, and, primarily, a large amount of ultraviolet radiation. They found the most favourable growth conditions at eastern localities where, while there is much light in autumn, temperature is higher than that at northern sites. Some fungi preferred western sites in spring.

Phenological fluctuations are observed in the occurrence of fungi in outdoor air. The air is mycologically cleaner in winter than in summer. A greater number of spores are recorded in air in spring and autumn than in winter and summer (Kruczalak et al. 2002). However, the greatest number of fungi in air is observed in autumn when all spring and autumn months are examined (Shelton et al. 2002; Daccaro et al. 2003). The results confirm this also in indoor air. There were fewer yeast-like 
fungi indoors in spring than in autumn and the species were not the same as those when the heating was on. A decrease in building insulation by airing did not affect considerably the composition of the mycobiota as a small percentage of fungi occurred both indoors and outdoors. Phenological changes of the indoor mycobiota were most probably caused not as much by changes of abiotic factors (temperature, radiation, humidity) as is the case with the external environment but by occupantrelated biotic factors. Pupils and the staff adapt their clothing and nutrition to the season; their immune systems also change. Changes in habitat parameters determine reorganisation of the species composition of all microorganisms, including fungi.

\section{CONCLUSIONS}

1. Indoor air in school buildings having normal humidity and temperature parameters can abound in yeast-like fungi: as many as 28 species of yeast-like fungi belonging to 15 genera were recorded. A total of 20 species belonging to 14 genera were identified in outdoor air.

2. Kluyveromyces lactis dominated in indoor air while Yarrowia lipolytica, a species characterised by the greatest symbiotic abilities, dominated in outdoor air.

3. A comparison of both habitats shows that a greater epidemiological risk of infection by yeast-like fungi is observed indoors rather than outdoors.

4. Intensely used rooms, especially where light access is limited, have the broadest spectrum of species of yeast-like fungi and therefore pose the greatest potential risk to the health of children and the school staff.

5. Indoor and outdoor air mycobiota changes phenologically although it is determined by other biotic and abiotic factors.

6. Species of yeast-like fungi that occur only indoors may be classified as "domestic fungi" while species recorded in outdoor air may be considered to be "field fungi".

\section{REFERENCES}

Angebauer C., Siebenhofer M., Mittelbach M., Guebitz G.M. 2008. Conversion of sewage sludge into lipids by Lypomyces for biodisel production. Bioresource Technology 99 (8): 3051-3056.

Arias C.D., Burns J.K., Friedrich L.M., Goodrich R.M., Parish M.E. 2002. Yeast species assiociated with orange juice: evaluation of different identitication methods. Appl. and Environ. Microbiol. 68 (4): 1955-1961.

Barnett J.,A., Payne R., Yarrow D. 1990. Yeasts : Characteristics and identification. Cambridge Univ. Press.

Biegańska M.J. 2006. Drożdżaki z rodzaju Candida - nie zawsze patogenne, ale... Mikol. Lek. 13 (4): 318-321.

Bogacka E., Matkowski K. 2001. Wpływ grzybów na zdrowie ludzi. Mikol. Lek. 8 (3/4): 175-178.

Bouchara J.P., Declerck P., Cimon B., Planchenault C., de Gentile L., Chabasse D. 1996. Routine use of CHROM agar Candida medium for presumptive identification of Candida yeast species and detection of mixed fungial populations. Clin Microbiol. Infect. 2 (3): 202-208.

Brandt M.E., Kauffman C.A., Pappas P.G., Iqbal N., Arthington-Skagga B.A., Lee-Yang W., Smith M. 2004. Fungemia caused by Zygoascus hellenicus in an allogeneic stem cell transplant recipient. J.Clin Microbiol. 42 (7): 3363-3365. 
Dacarro C., Picco A.M., Grisoli P., Rodolfi M. 2003. Determination of aerial microbiological contamination in scholastic sports environments. J. App. Microbiol. 95: 904-912.

Deak T. 2001. Identification of yeasts isolated from poutry meat. Acta Biol. Hungar. 52 (2/3): 195-200.

Desnos-Ollivier M, Ragon M, Robert V, Raoux D, Gantier JC, Dromer F. 2008. Debaryomyces hansenii (Candida famata), a rare human fungal pathogen often misidentified as Pichia guilliermondii (Candida guilliermondii). J Clin Microbiol. 46 (10): 3237-3242.

Dynowska M. 1991-1992. The influence of antibiotics on the morphology of Candida albicans and Candida stellatoidea. Acta Mycol. 27 (1): 205-211.

Dynowska M. 1995. Drożdże i grzyby drożdżopodobne jako czynniki patogenne oraz bioindykatory ekosystemów wodnych. Rozpr. hab. Studia i Materiały WSP, Olsztyn: 77: 1-83.

Dynowska M., Ejdys E. 1999. Grzyby chorobotwórcze dla człowieka. Biologia w Szkole 1: 21-26.

Dynowska M., Rosłan M., Góralska K. 2006. Sacharomyces cerevisiae in respiratory system, digestive system and on the skin in humans. Acta Mycol. 41(1): 139-144.

Ejdys E. 2007. Fungi isolated in school buildings. Acta Mycol. 42 (2): 245-254.

Ejdys E. 2008. Zasady biobezpieczeństwa i higieny pracy w laboratorium badawczym a przeżywalność grzybów potencjalnie chorobotwórczych. (In:) J. Garbacz (ed.). Diagnozowanie stanu środowiskametody badawcze - prognozy. Prace Komisji Ekologii i Ochrony Środowiska BTN, Bydgoszcz: 2: $63-70$.

Ejdys E. 2008a. Factors predisposing appearance of yeasts-like fungi in healthy school age girls and boys. Mikol. Lek.15 (2): 84-88.

Golubev W., Pfeifer I., Churkina L.G., Golubeva E.W. 2003. Double-stranded RNA viruses in a mycocinogenic strain of Cystofilobasidium informominiatum. FEMS Yeast Research 3 (1): 63-68.

Grajewski J., Twarużek M. 2004. Zdrowotne aspekty oddziaływania grzybów pleśniowych i mikotoksyn. Alergia 3 (21): 45-49.

Hahn T., Tag K., Riedel K., Uhlig S., Baronian K., Gellissen G., Kunze G. 2006. A novel estrogen sensor based on recombinant Arxula adeninivorans cells. Biosens. Bioelectron. 21 (11): 2078-2085.

Kondracki J. 2002. Geografia regionalna Polski. PWN, Warszawa.

Kreger - van Rij N.J.W. 1984. The yeasts. A taxonomic study. Third revision and enlarged edition. Els Sci. Publ. B. V., Amsterdam.

Krzysztofik B. 1992. Mikrobiologia powietrza. Wydawnictwo Politechniki Warszawskiej, Warszawa.

Kurnatowska A. 1998. Biologia i ekologia grzybów chorobotwórczych. (In:) E. Baran (ed.) Zarys mikologii lekarskiej. Volumed, Wrocław.

Kurnatowska A. 1999. Rezerwuary chorobotwórczych czynników biotycznych w aerosferze, hydrosferze i litosferze. (In:) A. Kurnatowska (ed.). Ekologia i jej związki z różnymi dziedzinami wiedzy. Wydawnictwo Naukowe PWN, Warszawa-Łódź.

Kurtzmann C.P., Fell J.W. 2000. The yeast. A taxonomic study. Elsevier Press, Amsterdam.

Mazurkiewicz-Zapałowicz K. 2006. A jednak metabolity grzybowe mogą być dobrodziejstwem ludzkości. (In:) J. Grajewski (ed.). Mikotoksyny i grzyby pleśniowe, zagrożenia dla człowieka i zwierząt. Bydgoszcz: 177-198.

Meklin T., Husman T., Vepsäläinen A., Vahteristo M., Koivisto J., Halla-Aho J., Hyvärinen A., Moschanderas D., Nevalainen A. 2002. Indoor air microbes and respiratory symptoms of children in moisture damaged and reference schools. Indoor Air 12:175-183.

Miklaszewska B., Grajewski J. 2006. Grzyby domowe. (In:) J. Grajewski (ed.). Mikotoksyny i grzyby pleśniowe zagrożenia dla człowieka i zwierząt. Bydgoszcz: 55-66.

Moreira S.R., Schwan R.F., de Carvalho E.P., Wheals AE. 2001. Isolation and identification of yeasts and filamentous fungi from yoghurts in brazil. Brazil. J. Microbiol. 32: 117-122.

Nagornaya S.S., Babich T.V., Podgorsky V.S., Beharav A., Nevo E., Wasser S. 2003. Yeast interslope divergence in soil and plants of "Evolution Canyon", Lowel Nahal Oren, Mount Carmel, Israel. Israel J.Plant Scien. 51 (1): 55-57.

Niedorzytko M., Chełmińska M., Jassem E., Częstochowska E. 2007. Association between sensitization to A. pullulans. Annals of Allergy, Astma and Immunology 98 (2): 153-156.

Polska Norma, PN 89/Z04111/03. Ochrona czystości powietrza. Badania mikrobiologiczne. Oznaczanie liczby grzybów mikroskopowych w powietrzu atmosferycznym (imisja) przy pobieraniu próbek metodą aspiracyjną i sedymentacyjną.

Shelton B.G., Kirkland K.H., Flanders W.D., Morris G.K. 2002. Profiles of airborne fungi in biuldings and outdoor environments in the united states. Appl. Environ. Microbiol. 68 (4): 1743-1753. 
Stach A., Piotraszewska-Pająk A., Stryjakowska-Sekulska M., Filipiak M., Silny W. 2004. Mikroflora powietrza wokół i wewnątrz budynków dydaktycznych wyższej uczelni w Poznaniu. Postępy Dermatologii i Alergologii 21 (3): 121-127.

Temprano J., Becer B.A., Hutcherson P.S., Knutsen A.P., Dixit A., Slavin R.G. 2007. Hypersensivity pneumonitis secondary to residential exposure to $A$. pullulans in 2 siblings. Annals of Allergy, Asthma and Immunology 99 (6): 562-566.

Topbas M., Tosun I., Can G., Kaklikkaya N., Aydin F. 2006. Identification and seasonal distribution of airborne fungi in urban outdoor air in an eastern Black Sea Turkish town. Turk. J. Med. Sci. 36: $31-36$.

Twarużek M. 2006. Grzyby pleśniowe i ich rola w środowisku. (In:) J. Grajewski (ed.). Mikotoksyny i grzyby pleśniowe, zagrożenia dla człowieka i zwierząt. Bydgoszcz: 17-34.

Wartman T, Kunze G. 2000. Genetic transformation and biotrchnological application of the yeast Arxula adeninivorans. Appl. Microbiol. Biotechnol. 54 (5): 619-624.

Zyska B. 2001. Grzyby powietrza wewnętrznego w krajach europejskich. Mikol. Lek. 8 (3/4): 127-140.

\section{Grzyby drożdżopodobne izolowane z powietrza budynków szkolnych i powietrza atmosferycznego wokół nich}

\section{Streszczenie}

Podobnie jak w powietrzu wewnętrznym, największą część bioaerozolu powietrza atmosferycznego stanowią elementy grzybni i zarodniki grzybów z różnych grup systematycznych. Duże zagęszczenie grzybów drożdżopodobnych w powietrzu może stanowić poważne zagrożenie dla zdrowia oddychająch nim dzieci. Dlatego też postanowiono zbadać występowanie omawianych grzybów w powietrzu budynków szkolnych i wokół nich.

Materiałem do badań były grzyby drożdżopodobne występujące przejściowo w powietrzu wokół budynków szkolnych oraz w ich wnętrzu. Grzyby pobierano w maju (ogrzewanie wyłączone) i listopadzie (okres grzewczy). Materiał uzyskano metodą sedymentacyjną Kocha, eksponując płytki Petriego z podłożem Sabourauda z chloramfenikolem oraz z różem bengalskim, w trzykrotnym powtórzeniu na każdym stanowisku. Ogółem uzyskano 111 izolatów grzybów drożdżopodobnych i drożdży właściwych, należących do 40 gatunków zgrupowanych w 19 rodzajach. W obu porach roku i typach badanego powietrza notowano tylko jeden gatunek -Kluyveromyces marxianus.

Stwierdzono, że powietrze budynków szkolnych, o prawidłowych parametrach wilgotności i temperatury, może obfitować w grzyby drożdżopodobne - 28 gatunków drożdżaków z 15 rodzajów. W powietrzu atmosferycznym zidentyfikowano 20 gatunków z 14 rodzajów. W powietrzu wewnętrznym dominantem był Kluyveromyces lactis, natomiast w powietrzu zewnętrznym Yarrowia lipolytica, gatunek o największych zdolnościach symbiotycznych.

Porównując badane siedliska zauważono, że w sensie epidemiologicznym, pomieszczenia szkolne stwarzają większe możliwości zakażeń grzybami drożdżopodonymi niż powietrze na zewnątrz budynków. Pomieszczenia intensywnie użytkowane, zwłaszcza z limitowanym dostępem światła, mają najszersze spektrum gatunkowe drożdżaków, a tym samym stanowią największe potencjalne zagrożenie dla zdrowia dzieci i pracowników szkoły.

Mikobiota powietrza wewnątrz pomieszczeń i na zewnątrz ich podlega zmianom fenologicznym, chociaż jest determinowana przez inne czynniki biotyczne i abiotyczne. Do „grzybów domowych" można zaliczyć gatunki drożdżaków występujące tylko w pomieszczeniach, natomiast gatunki pochodzące z powierza atmosferycznego można uznać za „grzyby polowe”. 